\title{
FORESTRY PRACTICE-EXAMPLES OF, AND PROGRESS IN CONSTRUCTIVE WOODS OPERATIONS
}

\section{By J. D. GiLmour}

This report will show in a general way what the writer considers to be progress in what is coming to be called "Industrial Forestry," defined as the conscious growing of timber commercially.

Canada undoubtedly still possesses very large quantities of commercial timber, and has further, an unusually large proportion of absolute Forest land, both East and West. The economic conditions surrounding Forest Operations are extremely variable in a country of this size; also the uses of timber. We should expect to find greatest advancement in industrial forestry where economic conditions are most favorable. Such conditions are becoming more favorable first in the East. Here we find several hundred million dollars invested in pulp and paper mills which need a long period of life to justify their existence, consequently must practice Industrial Forestry. In the west, so far as the writer is aware, only very small beginnings have yet been made by the timber owners in the practice of Forestry. Governments have, however, made, and are making, in the West, extremely valuable silvicultural studies which will be applicable when economic considerations warrant them.

In the East the picture is already different, and while advances made are not very apparent as yet, they are of extreme and increasing importance.

The subject may be divided in general, as follows:-

1. Protection against fire, insects fungi,--that is, seriously attempting to hold what we have. The writer will not elaborate on this, because all members know the situation fairly well. It will suffice to say that these problems of late years receive increasing attention, and that not only Governments, but private owners are spending, willingly, a lot of money in these directions.

2. Employment of Trained Foresters-It is not necessary to elaborate this point either, except to state that forest properties are constantly coming more and more under the supervision of foresters. This may seem so natural an evolution as not to require comment, yet such a development has practically all taken place in the last twenty years, not a very long time in the life of a state, or of a forest.

3. Taking stock of resources.-That is, finding out what we have. This is actually being done by nearly all large Eastern Companies, and the total areas so studied already come to many thousands of square miles. This, after Fire Protection, is the first essential to the practice of forestry, leading as it does to the preparaion of working plans, and to more intelligent logging. Not only is the quantity determined, but types, age, classes, condition of timber, increment and mortality of different age-classes, are studied. As 
a rule, topography is mapped. Consequently a working plan can be made, which is pure forestry, and yet the cost of the work may be to a considerable extent recovered in cheapened cost of Logging. The reason for this is that more accurate information allows of better planning of Logging Operations.

In certain Provinces, the preparation of a forest working plan, designed to put the land in a perpetually producing state, is obligatory on operators, and must be approved by Provincial Forestry departments. Even where this is not required, there are already owners who are starting this procedure on their own account.

4. Silvicultural Experiments and Studies.-In other words, finding out how to keep forest land productive after the first crop is taken off. It may be said here, that all progressive companies have in progress silvicultural studies of diverse kinds, formulated and worked on by their foresters. While it must be admitted that a great many more are still in the experimental stage than are yet applied on a large scale commercially, the fact that such silvicultural studies are being made is of the first importance. It argues a growing consciousness on the part of owners and managers that forests must be made perpetual if economically possible to do so. This, after all, is the most important and encouraging feature.

If there is delay in putting silvicultural practices into effect thoroughly, and on a large scale, it appears to the writer to be due more to the necessity for years of study by foresters before they know exactly what they can best do with their particular problem, than to reluctance on the part of management. However, such studies are undeniably being made in very many places. As soon as foresters can show the possibilities in the commercial application of silvicultural methods and recommend such practices they will in many cases be adopted. In certain cases Foresters have already done so, and are actually applying them to logging operations on a large scale.

Actual examples of applied forestry on a commercial scale: -Without going into details as to exact areas or naming any particular company, the writer has obtained knowledge of all the following as being practised commercially:-

(a) Planting of soft wood species.

(b) Broadcast seeding.

(c) Seeding in spots.

(d) Thinning in immature stands.

(e) Brush burning.

(f) Foregoing present profits by leaving seed trees where natural regeneration is sparse or lacking.

(g) Leaving a belt of seed trees around edges of bare areas and burns in hopes that restocking may be obtained. 
(h) Marked improvement in conservation through smaller tops, etc., but more particularly through use of inferior species, even hard woods, and the use of defective wood which was formerly left in the woods.

No apology is necessary if this report seems to ignore largely commercial application of forestry principles to saw timber production in Canada. Whatever may be under way in that direction must as yet be of small extent, and the writer must admit is unknown to him. There is on the other hand, considerable real advance, though yet a very long way to go, in the practice of forestry in the pulp and paper business. This is logical economically, and is particularly important to Canada because of the outstanding place occupied by the pulp and paper industry in Canada's commercial structure.

Canadian Foresters have here a field worthy of their best efforts, and will find an increasing realization by the management in this industry that they need "Industrial Forestry" just as soon as possible. 